\title{
LATEST ATTEMPTS IN CONTEMPORARY IRANIAN ARCHITECTURE IN SEARCH FOR AUTHENTICITY
}

\author{
Ghazal FARJAMI (D) ${ }^{1, *}$, Guita FARIVARSADRI (1D ${ }^{2}$ \\ ${ }^{1}$ Department of Interior Architecture, Faculty of Architecture, Final University, Via Mersin 10, Girne, Turkey \\ 2 Department of Interior Architecture, Faculty of Architecture, Eastern Mediterranean University, Via Mersin 10, \\ Famagusta, Turkey
}

Received 09 March 2020; accepted 04 November 2020

\begin{abstract}
The conflictions between homogeneity and universal values suggested by Modernism and traditional values resulted in a variety of ideas generated as a search for authenticity all over the world. Iran is known as one of the countries which imported the modern ideas directly to a society, which was still living with and respecting the traditional values. This challenge between the two seemingly conflicting poles of tradition and modernism resulted in three periods in the history of contemporary Iranian architecture. Now, it seems that Iranian architecture has entered to a new period regarding the interpretation of authenticity. Since novelty and relation with the past are known as the main indicators of the concept of authenticity, in this research it is tried to explore the ideas of seven pioneers of the new generation of architects in Iran around these concepts. These architects are amongst the most well-known young architects of Iran who have won more than 3 prizes in Memar (Architect) competition which is the most prestigious architectural competition in the country. To find out the interpretation of these architects about the concept of authenticity, inclusive interviews have been realized with these architects. Then, using recursive abstraction method, it is tried to find out the main points in definition of the concept of authenticity by each architect. In addition, some of the completed projects of theses architects have been visited and analyzed to find out the reflection of their ideas related to authenticity in their projects.
\end{abstract}

Keywords: authenticity, Iranian architecture, novelty, relation with past, traditional architecture.

\section{Introduction}

Due to the radical rupture of modern architecture from traditions, variety of debates around authenticity and what is authentic architecture has been developed in various countries. Iran was a country with rich traditions when it inevitably encountered modernity. The challenge between modern and tradition resulted in different approaches in various periods of time towards the concept of authenticity in this country. Looking for authenticity, three different periods can be detected in contemporary Iranian architecture up to the beginning of the $21^{\text {st }}$ century. But now a new generation of architects with different viewpoints from their predecessors is emerging in Iran. This paper will try to find out how this new generation of architects looks at the concept of authenticity, the relation with the past and search for novelty.

For this purpose at the first step a research have been done on the concept of authenticity and its indicators. Then in the light of these definitions the development of concept of authenticity in the Iranian architecture and how it evolved throughout the $20^{\text {th }}$ century have been investigated. As the last step of this research interviews have been realized with 7 successful Iranian architects from the new generation and their works have been visited and analyzed to find out from a first-hand source how the new generation of architects perceive the concept of authenticity and discover the difference of their approach with the ones of the previous generations. To decide about which architects can be the representatives/ pioneers of the new generation of architects in the country, the architects who have won more than 3 prizes in Memar (Architect) award which is the most prestigious architectural competition in Iran have been selected. These architects are: Reza Daneshmir, Alireza Taghaboni, Rambod Eilkhani, Pouya Khazaeli, Mohammad Majidi, Ramin Mehdizadeh, and Arash Mozaffari. These architects' works have been also introduced in recent volumes of very prestigious international journals as the pioneers of Iranian architecture.

${ }^{*}$ Corresponding author. E-mail: qazalfarjami@gmail.com

Copyright $\odot 2020$ The Author(s). Published by Vilnius Gediminas Technical University

This is an Open Access article distributed under the terms of the Creative Commons Attribution License (http://creativecommons.org/licenses/by/4.0/), which permits unrestricted use, distribution, and reproduction in any medium, provided the original author and source are credited. 
After this selection, in depth and inclusive interviews were carried on with each of these architects. Open ended questions regarding the concept of authenticity were used in these interviews. As the second step of the research using recursive abstraction method, the main points related to authenticity and its two main indicators (novelty and relation with the past) have been extracted to be used in the analysis of their architectural works. In this article as a qualitative research, a summary of all interviews, including the main approaches of each of these architects is provided by coding them based on indicators of the concept of authenticity. Later, a comparative table including the main points emphasized by each of these architects in relation to two indicators of authenticity have been prepared to find out the common points in their approaches and its difference with the previous ones.

\section{Concept of authenticity}

To begin the discussion it is needed to define the concepts of authenticity, which involves the reassessing of basis and foundation of something in its origins. Porphyrios, names the quality of being authentic as classical which is the tradition in a modern voice (Porphyrios, 1998). William Curtis too sees this quality as a modern tradition, which can be defined as new interpretation of age-old lessons (Curtis, 1983). Gadamer mentions that we could recognize history because it has made us and we inherit its experiences and also we base the foundations of our future on the situations past created for us (Warnke, 1987). Frampton also supports this idea where he points out that innovation can be achieved just through rereading, remarking and recollecting the traditions which can be revitalized just by the means of innovation as a two way relation (Frampton, 1996).

Proposing more richly new ideas it would be better to study what has been done before in order to become familiar with the ideas of the predecessors otherwise it would be an architectural entity which is just about details instead of principles which can result in beautiful individual parts while it doesn't match with the whole (Kindler, 1974). Furthermore, Porphyrios in the book of Classical Architecture mentioned that "An artist is said to be original exactly when he takes up the challenge of tradition and makes us see something more than we already know. Originality, and thus the modern itself, consist in this distance between the new and the model as the new employs itself within tradition" (Porphyrios, 1998).

Therefore, novelty and relation with past are both the foundations of being authentic while ignoring each of them will takes us far from this concept. It has to be considered that neither the mere novelty nor any kind of returning to the past can be resulted in creating an authentic artwork.

\section{Challenge of modern and tradition in Iranian architecture}

The two main indicators of the concept of authenticity, novelty and relation with past, can be followed in Iranian architecture after modernism. However, it was not that simple to be in relation with past while creating something new. After all, it was not the taste modifications, which changed the architecture, but the changes in lifestyle, attitudes and the public culture since architecture is the expression of what has been transformed from past to present time and it has to carry all those memories and emotions in order to make relation with the people of its society (Bavar, 2008). It can be acclaimed that there are two main approaches towards tradition. One is about referring to the principles and ideas ingrained in religious, natural and innate aspects of tradition and the other, is mostly about the terrestrial and material aspects of it (Ahadi, 2011).

The ideas of modern movement reached to Iran while the majority in society were still following traditional values and had very traditional lifestyles. Thus, society witnessed a great challenge between the modern and tradition's values. Architecture was also affected by these conflictions, which resulted in formation of four distinct periods in contemporary Iranian architecture between 1920- today. This division is mostly based on the attitudes of architects towards authenticity, which in modern approach has been defined as the challenge of modern ideas and traditional terms.

In the first period of contemporary Iranian architecture from 1920 to1940 one can see the vast usage of traditional forms. As Mirmiran mentions, in this period the most important buildings were monumental governmental ones designed by the foreign architects invited to Iran. Thus in many of the works of architecture an imitation and direct use of historical architectural forms that symbolized the magnificent Iranian history can be traced (BaniMasoud, 2009). The main design principle in this period has been following the forms of Iranian ancient architecture. Figure 1 shows some examples of Iranian ancient architecture and the usage of them in the works of the architects of this period. The place of tradition has been mainly defined as superficial and apparent repetition of elements, forms and motives used in the buildings of Achaemenid and Sassanid era (Mirmiran, 1999). This Iranian romantic historicism draws the attention of many historians, who may have had a nationalist interest in the presentation of an Iranian image in the architecture of this period (Hasanpour et al., 2015).

The second generation of architects in Iran from 1940 to1970s in search for an authentic Iranian architecture used geometric patterns and forms of traditional architecture in their works. Although, during this period the architects tried to create modern forms they also combined it with geometries and also patterns of Iranian architecture in search for Iranian identity (BaniMasoud, 2009). It should be mentioned that this was not anymore a mere direct imitation of some patterns and forms. The patterns used were abstracted and modified and merged into a contemporary architecture. All cultural motives were used in architecture (Soheili, 2012). In this regard Mirmiran (2004a) states that: 
"The second group works addresses Iranian culture on a broader scale with its myths, concepts, cultural contents and memories. These works have benefited from other artistic fields such as poetry and literature for intellectual innovation in architecture" (Mirmiran, 2004a).

Figure 2 demonstrates some examples of Iranian architecture from Safavid period and some works of Iranian architects between the years 1940-1970 that are inspired by theses traditional motives and patterns.

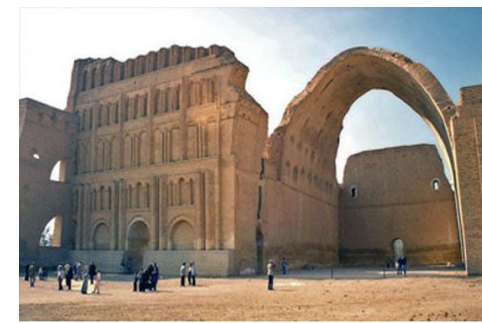

(a)

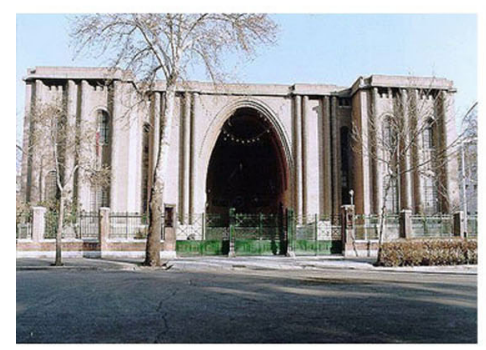

(b)

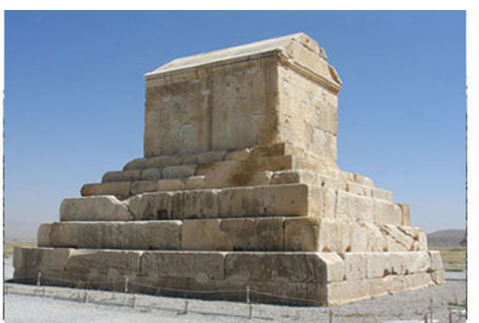

(c)

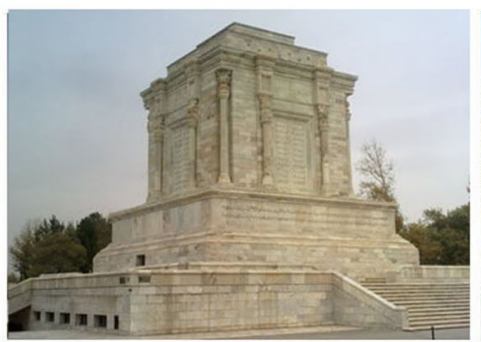

(d)
The third period seems to be an attempt for balancing the relation between the usages of new technological improvements with traditional ideas. From 1970's to 2000 it has been tried to extract meanings and implications of traditional Iranian architecture and convert them into new modern buildings. So in this period constructions based on various theories become more prevalent. Also, acknowledging the meanings of older Iranian architecture was seen as important, and searching for quality of

Figure 1. Examples of Iranian ancient architecture and the usage of them in the works of the architects of the first period: (a) Iwan Madaen from 224 CE in Iraq (Asgharzadeh \& Mehrnazar, 2009); (b) National Iran Museum in Tehran by Andre Godar, 1934 (Rahimazadeh, 2007); (c) Kourosh Tomb in Psargad from 600 BC (Author, 2011); (d) Ferdosi Tomb in Khorasan by Karim Taherzadeh, 1934 (Author, 2010); (e) Apadana Place in Persepolis from 486 BC (Author, 2010); (f) Shahrbani Palace in Tehran by Henrish from 1936 (Jadidonline, 2005)

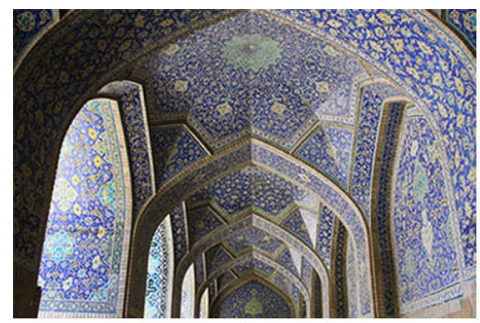

(a)

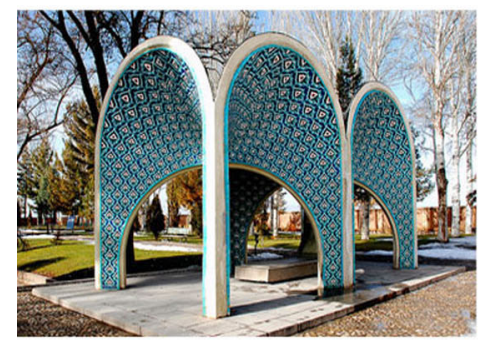

(b)

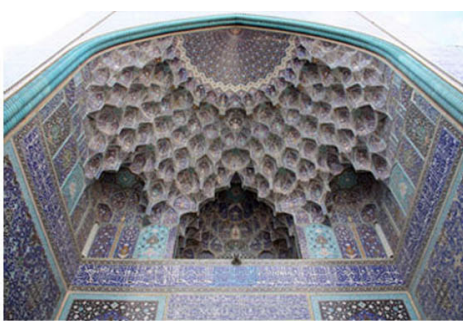

(c)

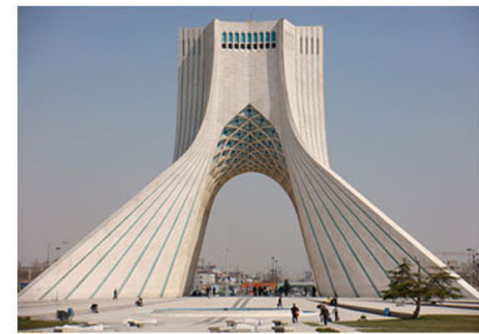

(d)

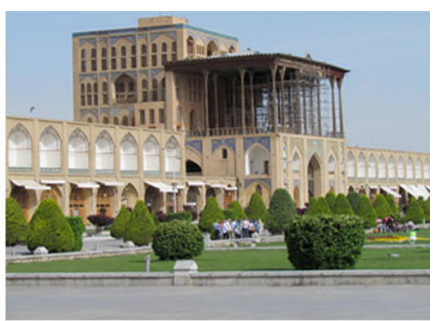

(e)

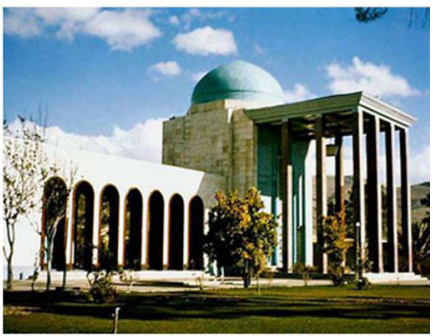

(f)

Figure 2. Examples of patterns of historical Iranian architecture as sources of inspiration for Iranian architects between the years 1940-1970: (a) Imam Mosque from 1611 in Isfahan (Veisi, 2008); (b) Kamal-ol-Molk Tomb by Houshang Seihoun in Khorasan, 1963 (Mansour, 2003); (c) Moqarnas; (d) Azadi Square in Tehran by Hossein Amanat, 1970; (e) Ali Qapou from Safavid era (Author, 2011); (f) Saadi Tomb by Mohsen Foroughi, 1951 


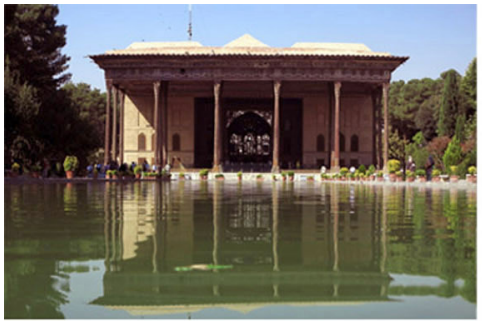

(a)

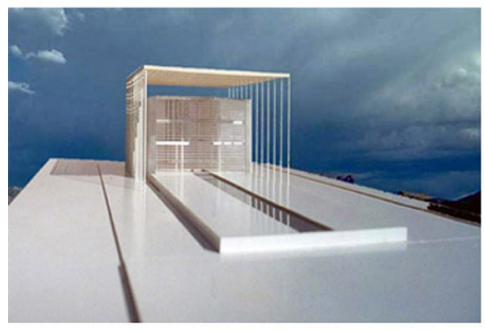

(b)

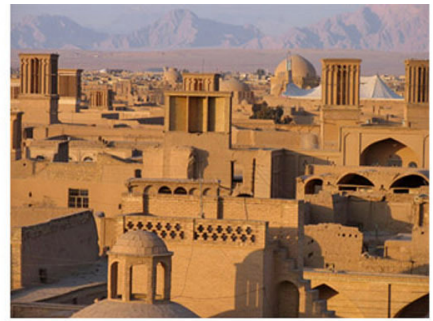

(c)

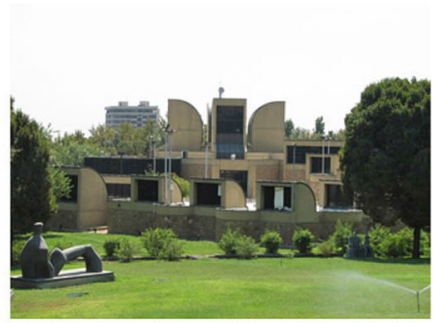

(d)

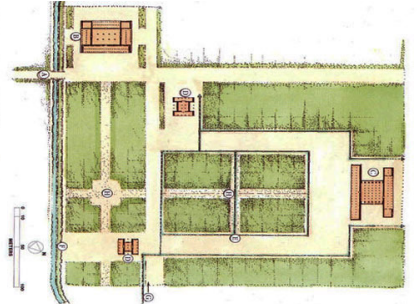

(e)

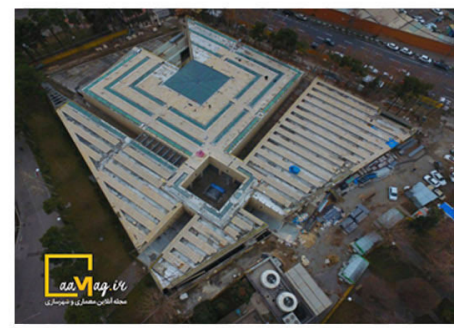

(f)

Figure 3. Examples of interpretation of concepts and patterns of traditional Architecture by the architects of the third generation: (a) Chehel Sotoon Palace from 1646 in Isfahan (Palmer, 2009); (b) Embassy of Iran in Zimbabwe by Hadi Mirmiran (Mirmiran, 2003); (c) Windcatchers in Kashan (Iranian Cultural Heritage, Handcrafts and Tourism Organzation [ICHHTO], 2014); (d) Museum of Contemporary Arts by Kamran Diba in Tehran, 1977 (Author, 2011); (e) Traditional Iranian Garden's pattern (Bahmani \& Karimi, 2015); (f) Library of Science and Technology University in Tehran by Farhad Ahmadi from 2010 (aaMag.ir, 2017)

the space became the central discussion instead of merely thinking about the forms (Bavar, 2008).

According to Darab Diba, an architect of this period traditional architecture is based on some principles that can be used to create architecture, which is adjusted with environmental and cultural issues of the period it belongs to (Diba \& Dehbashi, 2004). Mirmiran (2004b) divides the works of architects in this period to three groups: a) Those which offer a new interpretation of traditional patterns, b) those which address Iranian culture on a broader scale with its myths, concepts, cultural contents and memories and c) those (mainly emerged between 1997-2002) which at one hand follow the world's progressive architectural discourse, and on the other hand used concepts of traditional architecture in their works. In Figure 3 some examples of interpretation of traditional concepts and patterns of Iranian Architecture by architects of this period can be seen.

\section{New approaches towards the idea of authenticity in contemporary Iranian architecture}

It seems that in the years after 2000, the search for identity in Iranian architecture has entered a new era. In this respect Ghorbani mentions that in Iran, the recent economic crisis created opportunities for experimental architectural practices. It has also resulted in a new policy of tradition that has embraced the desire to recreate the local-global dynamics of "Iranian identity" (Ghorbani, 2019).

According to Farahi the strength point of today's Iranian architecture consists of two groups consisting of practitioners; prominent international Iranians with a remarkable theoretical background and knowledge of contemporary architecture and a wide range of national architects with diverse regional experience (Farahi, 2012). Dariush Shaygan, the great Iranian philosopher, states that hypertextual dialogue has "one foot in prehistoric culture and the other foot in the metamorphosis of the future" (Shaygan, 2001).

Traditional ways of thinking about tradition have also been recently challenged. The new approach to authenticity demonstrates "less as an entity, but as a process through which ideas and practices New Instead of Sweeping" (Ghorbani, 2019). This way of thinking about tradition allows the constructed environment to be viewed as a "set" of adaptive and changeable practices rather than aesthetic images and romantic modified forms (Ghorbani, 2019). The concepts of identity, culture, tradition and history are key to understanding contemporary Iranian architecture. Darab Diba explains how the Islamic revolution of Iran in 1979 failed with an approach that for almost two centuries directly equated modernity with Western influence. The revitalization of interest in "Iran" itself was initially shown by historical interest in the past, but has recently changed to a complex assessment of the country's heritage (Diba, 2012).

Since, in Iranian architecture modern identity has not yet been determined, many existing contemporary buildings exhibit a kind of eclectic architecture. Therefore, the appropriate response to the construction of contemporary buildings must respect both contemporary needs and cultural demands (Mokhtarshahi Sani \& Mahasti, 2013). Examining different ideas about architectural identity in general indicates diversity or differences in the approach 
of contemporary architects in the relevant strategies. Accordingly, while some focus on originality and stability, the others focus on creativity and dynamism. Some see it as belonging to the past and some as identity as part of the future (Habib et al., 2013). The significant point of all these viewpoints is the focus and different approaches towards traditional Iranian architecture archetypes and concepts which are all common in Neo-classicism, Eclecticism, interpretation and making dialogue with the world architecture (Mahdavinejad et al., 2012).

Using global thinking, Iranian architects, with the approval and use of today's technological facilities, inspired by the global abstract expression of Iranian architecture, are trying to provide ways to determine a new direction in the windows of pluralism and innovation (Diba, 2011). The issue is no longer the search for cultural forms, but the understanding and intellectual awareness of what has always been the conceptual and philosophical essence of Iran's artistic heritage (Axworthy, 2007).

These different approaches to identity and authenticity in Iranian architecture still are not well documented. Haj Maleki and Haghir (2020) state that apart from a few journalistic texts about specific periods or moments in the history of contemporary Iranian architecture, which only reveal the personal tastes and opinions of their authors on specific aspects of architecture, there is still no written history based on fixed historiography methods that can be used as a reference for a better understanding of contemporary Iranian architecture and the identification of different styles and theories (Haj Maleki \& Haghir, 2020).

Since the aim of this research is to find out how the new generation of Iranian architects approach to the concept of authenticity, it is tried to clarify this issue from the viewpoints of seven pioneer contemporary architects. As mentioned before these architects are some of the most well-known young architects in Iran with whom inclusive interviews were done. The following paragraphs are a summary of what they have mentioned in these interviews regarding the way they see the concept of authenticity. Moreover, to clarify how these statements have been demonstrated in their architectural works analyses of some of their works are added too.

According to Reza Daneshmir, originality relates to an exclusive idea, which can be posed and developed in order to become an architectural project. About relation to the past he believes that there are different attitudes towards looking to the past; some are traditionalists who believe in complete turn back to the past, some are futurists who just move to the future and their idea is creating novelty, and others are the combination of these two who try to update the ideas of past. Thus, he is not concerned about whether it is related to the past or not or how it can be related to the future but the important issue for him is what can be done in the present time, and how the subject can be seen from a new perspective. To sum up, he is looking for ideas which make changes, not the ones which express the existing or even old conditions.
In this regard he mentions that "what we can do is to examine how solids and voids have been combined in traditional architecture and to explore the ideas behind them." That is the reason he tries to connect buildings with the city through open spaces in his works. His architecture is an attempt for designing buildings which actively participate in their contextual background such as Mellat Cineplex building or Commercial-Residential Complex that due to created voids in their designs do not interrupt the continuity of open space and landscape in the city.

Analyzing his projects shows that using central open spaces which reminds of central courtyards of traditional architecture is one of the dominant authentic characteristics in most of his projects. Daneshmir has tried to use the idea of central emptiness especially vertically for creating a balance between solid volumes and voids. He also uses this issue for conducting a dialogue with city and connecting the building with infinite space of the city. Reinterpretation of traditional central courtyards in Daneshmir's projects shows a different determination of being authentic. Table below demonstrates how Reza Daneshmir has interpreted the use of central open space, an important characteristic of traditional architecture of Iran in some of his designs (Table 1).

Alireza Taghaboni one of the other pioneering architects in Iran defines the concept of originality on the basis of hermeneutic, which means presenting a new interpretation of an older idea. In other words, to him, authenticity is about attaining a deep attitude through which designers can present new interpretations of themselves and others. Taghaboni also expresses that authenticity is a modern implication of positivism through which people believed that human can achieve the pure reality with his knowledge. In architecture it means that an architect can create the absolute and pure reality and present it as the only unchangeable correct thing. That is why originality became an important issue. He also states that today no one uses originality with its modern meaning. A creative interpretation of a project can be so much interesting and include so many implications that promote it to an artistic work.

In regard to relation with past Taghaboni expresses that the new generation of architects show a great tendency for returning to traditions. He also emphasizes that he does not do these consciously because it will be worthy when it comes from inside, from one's culture and background. It seems that Taghaboni's projects are attempts for creating architectural works that are in strong relation with their context. He tries to have new interpretation of typology of the traditional context. Designing buildings with central open spaces or gable roof show his desire for creating buildings in harmony with their surrounding environment (Table 2).

Rambod Eilkhani, as one of the other Iranian contemporary architects of the recent generation states that authentic work is not the one, which is necessarily new. However, authentic architectural entity is the one, which is in continuation of the others. According to him instead 
of relating our works to the past and tradition if we try to promote what we have today it can be authentic because what exists has a background behind and has passed through history to reach to this point. It is true that in Iran there have been historical ruptures in architecture but these interruptions formed a part of Iranian history. This separation from historical roots which could be related to war, revolution or such events is also part of the history. Therefore, what we have today is ingrained in previous attempts even though it has been ruptured in some periods. He believes that the architect's mission is to improve the existing works; it is not possible to take something out of pocket and call it a new work. Authenticity is about continuing and promoting what we have today.

Table 1. Interpretation of central open spaces for creating a play between solid and void in Daneshmir's projects

\begin{tabular}{|c|c|}
\hline Definition of Authenticity & Projects \\
\hline $\begin{array}{l}\text { Relation with past } \\
\text { - Not to rob from past but to add to what exists } \\
\text { - Expanding the boundaries of tradition } \\
\text { - Proposing an exclusive idea beyond the mere } \\
\text { program of the project }\end{array}$ & $\begin{array}{l}\text { New interpretation of traditional central courtyards as vertical open spaces } \\
\text { which connect the building with the city (Author, 2016) }\end{array}$ \\
\hline $\begin{array}{l}\text { Novelty } \\
\text { - Play of solid and void } \\
\text { - Integrating the building with the infinite } \\
\text { space of the city and context }\end{array}$ & $\begin{array}{cl}\text { Vertical open space in Mellat Cineplex } \\
\text { in Tehran (Daneshmir, 2008) }\end{array} \quad \begin{array}{l}\text { Vertical open space in Pol Rumi Office } \\
\text { Building in Tehran (Daneshmir, 2008) }\end{array}$ \\
\hline
\end{tabular}

Table 2. Compatibility with typology of traditional architecture and surrounding context as authentic features in Alireza Tghaboni's projects

\begin{tabular}{|l|l|l|l|}
\hline \multicolumn{1}{|c|}{ Definition of Authenticity } \\
- Harmony with typology of traditional \\
context \\
- Changeable interior spaces by play of \\
light and shadow \\
- Rough texture \\
- Concept of duality (solid and void, \\
open and close)
\end{tabular}


Eilkhani mostly tries to push the limits of construction regulations to use the blind spots where there is nothing written in rules. For instance, one of the important issues in "2offices, 2 brother" project has been dealing with these regulations. Dealing with the dilemma of market and construction rules on one hand and necessity of having open spaces in such compact contexts on the other hand resulted in emerging new ideas. For instance, in this project public open spaces have been used as private ones. Since, in traditional architecture relation with nature and context were always important he tries to reuse them in a new way which can be adapted to new lifestyles as well. He also mentions that flexibility and dynamicity of interior spaces and facades are the major concerns of him related to traditional architecture.

In Dollat II project and Khorsand Office Building, there is a narrow alley in front, which doesn't let to have cantilever toward the street, which is why he designs a flexible façade. Rambod Eilkhani, directly points to dynamicity as an authentic representation of lightness. In his designs he employed dynamic moveable surfaces on façades which remind of huge windows covering the whole façade of traditional buildings named Orsi. In traditional buildings opening of these glasses resulted in total trans- parent relation between inside and outside while closing them created discontinuation of visual and physical relation with outside due to the colored stain glass parts.

Considering the chaos and eclectic feature of new urban contexts in Iran, Rambod Eilkhani attempts to create neutral simple facades, which connect these heterogeneous urban units together rather than adding other strange features to them, which reminds of simplicity and integration of traditional architecture (Table 3).

According to Pouya Khazaeli another well-known figure in contemporary Iranian architecture, the built entities can be classified into two categories of architectural and non-architectural works. In his opinion the ones, which are architecture, are authentic as well. Because, he believes that for creating an architectural work it is not possible to think instantly and create something, but it needs a background, which supports it. He states that it is not about imitation but for creating a real architectural work it is needed to start from somewhere which exists before. If designers start from that point their works not only won't be like previous ones but would also carry the implications and this is what would give them authentic characteristic.

According to Khazaeli, the most important factor in making relation with past in an architectural work is the

Table 3. Dynamicity and flexibility of interior spaces and facades as an authentic feature in Rambod Eilkhani's projects

\begin{tabular}{|c|c|c|}
\hline Definition of Authenticity & Projects & \\
\hline $\begin{array}{l}\text { Relation with past } \\
\text { - Dynamicity of façade and interior } \\
\text { spaces } \\
\text { - Flexibility of façade and interior } \\
\text { spaces } \\
\text { - Relation with nature } \\
\text { - Integration with context }\end{array}$ & 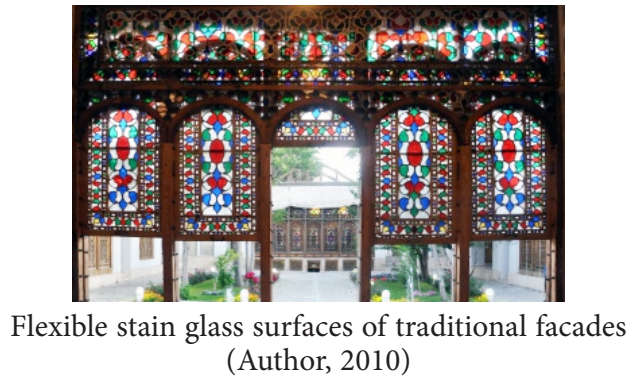 & 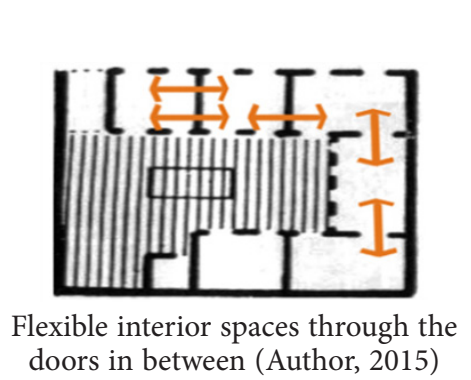 \\
\hline $\begin{array}{l}\text { Novelty } \\
\text { - Not necessarily new but being in } \\
\text { continuation of what exists before } \\
\text { - Promoting what we have today } \\
\text { - New interpretation of what exists }\end{array}$ & New interpretation of flexible facades in Khor- & $\begin{array}{l}\left.\square \longrightarrow \prod\right\rfloor \\
\text { Flexible interior space organization } \\
\text { by locating service areas aside and } \\
\text { indeterminate spaces (Author, 2015) }\end{array}$ \\
\hline & New interpretation of flexible facades in Dolat II & $\begin{array}{l}\text { Flexible interior space organization } \\
\text { by locating service areas aside and } \\
\text { indeterminate spaces (Author, 2015) }\end{array}$ \\
\hline
\end{tabular}


idea behind it. He mentions that in traditional architecture, buildings have never been separated from their surroundings, people, society and all elements around them; the materials used in the construction of the buildings, the respect for the culture and way of life in building design, etc. are all demonstrations of this fact. He does not talk about forms because it includes wider meanings and implications. What he sees as significant in traditional architecture can be summarized as three main characteristics: 1. Being in relation with its context, 2. Being independent, 3. Being new.

The first criterion is about the ways of making connection with surrounding environment. The second one is about the fact that for example in contrary with today's architecture which is dependent on concrete and on private energy sources especially fossil energy, while in traditional architecture they dug the ground and used that soil for construction of the building. The third one is about the fact that today we try to act abnormal. In other words, in nature, whatever comes to being, dies after sometime and then it becomes alive again in some other forms like seasons. On the other hand, designers try to create eternal entities in opposition with nature. For instance, architects try to create concrete buildings, which remain forever. In time, these buildings get old and although they may physically exist but they become obsolete.

According to Khazaeli architects are supposed to use technology for making relation with nature which is not just about greeneries but it includes every element and parameter of building's context. Dealing with light and duality between modern ideas and principles of Iranian architecture are dominant in his projects (Table 4).

According to Ramin Mehdizadeh from the artistic point of view, architecture is authentic when it includes a part of designer's idea coming out of his own mind and it is not about imitation. Here is where these two can be separated from each other. Yet, it is difficult to distinguish them because each year millions of projects with similar concepts are built and we are under the influence of what we see.

Although, the importance of background and experiences cannot be denied, the more important thing is the way the filters in designer's mind work. When searching for an idea in design, these experiences will help architect in achieving a purer idea and this comes from architectural education through which the bases for judging what is right and what is wrong is given. Therefore, there are some rules in architect's mind and whenever ideas pass through theses filters of mind and find their own language they can be called authentic not when they have been borrowed from the others and there are no traces of their own unique language.

While designing a project firstly he tries to find out the problem and pose a question according to that, similar to writing a scenario and the resulted architecture is the respond to that question. He mentions that may be not directly but undoubtedly his attitudes have been under the influence of traditional architecture of Iran.

As an example he gives the example of Apt. No. 1 where he tried to reuse the waste materials of stone factories

Table 4. Combination of modern and tradition ideas for the sake of authenticity in Khazaeli's works

\begin{tabular}{|c|c|c|}
\hline Definition of Authenticity & \multicolumn{2}{|c|}{ Projects } \\
\hline $\begin{array}{l}\text { Relation with past } \\
\text { - Starting from somewhere which exists } \\
\text { before and proposing something new } \\
\text { - Combination of modern ideas and } \\
\text { principles of Iranian architecture }\end{array}$ & $\begin{array}{l}\text { Combination of Introverted traditional } \\
\text { central courtyard houses and typology of } \\
\text { gable roof buildings (Author, 2017) }\end{array}$ & $\begin{array}{l}\text { Combination of Introverted traditional } \\
\text { idea with extroverted idea of modern } \\
\text { architecture (Author, 2017) } \\
\text { of moversion } \\
\text { architecture } \\
\text { architecture }\end{array}$ \\
\hline $\begin{array}{l}\text { Novelty } \\
\text { - Not to be separated from surround- } \\
\text { ings } \\
\text { - Being independent } \\
\text { - Being new } \\
\text { - Dealing with light }\end{array}$ & & Ins \\
\hline & $\begin{array}{l}\text { New interpretation of central courtyard } \\
\text { houses and gable roof buildings with } \\
\text { extroverted idea of modern architecture in } \\
\text { Darvish Villa (Khazaeli, 2010) }\end{array}$ & $\begin{array}{l}\text { New interpretation of central courtyard } \\
\text { houses and gable roof buildings with } \\
\text { extroverted idea of modern architecture in } \\
\text { Darvishabad Villa (Khazaeli, 2010) }\end{array}$ \\
\hline
\end{tabular}


around the city. These stones were free and the workers' fees for the work were lower. Therefore, the least energy was spent by creating a local building. At this point this work can be called authentic because there was a question, which was solved with his project and afterwards others started to use it (Table 5).

Arash Mozafari one of the other contemporary Iranian architects of the last generation mentions that obviously, authenticity is related to climatic and cultural issues of the context. There are so many debates around this issue; when Iranian architects design projects, naturally they be- come Iranian because of their Iranian lifestyle, which is ingrained in them.

According to him simulation is not bad but imitation is. When you are imitating you are copying something from something else but when you are simulating it can enter to an evolutionary process, which can be resulted in authenticity. Originality for him is not necessarily about creating something new that no one has seen before. He believes that time for these discussions are over.

Considering the relation with past, Mozafari names some criteria one of which is about implications and the

Table 5. Enhancing 3dimensional quality of space and integration with context by usage of local materials in Mehdizadeh's works

\begin{tabular}{|l|l|}
\hline \multicolumn{1}{|c|}{ Definition of Authenticity } \\
- Usage of local material \\
- Integration with context \\
- Enhancing 3dimensional quality of \\
space
\end{tabular}

Table 6. Idea of core and crust in the works of Arash Mozaffari with reference to traditional Iranian gardens

\begin{tabular}{|c|c|}
\hline Definition of Authenticity & Projects \\
\hline $\begin{array}{l}\text { Relation with past } \\
\text { - Usage of local material } \\
\text { - Integration with context } \\
\text { - Enhancing 3dimensional quality of } \\
\text { space }\end{array}$ & $\begin{array}{l}\text { Pattern of traditional Iranian Gardens with a central building surrounded by greeneries } \\
\text { interpreted as a transparent shell covered the solid volume (Mozafari, 2009) }\end{array}$ \\
\hline $\begin{array}{l}\text { Novelty } \\
\text { - Novel idea and relation with past } \\
\text { - Ideas passed through the filter of de- } \\
\text { signer's mind and carrying their own } \\
\text { language }\end{array}$ & $\begin{array}{l}\text { Idea of core and crust inspired by Iranian } \\
\text { gardens in Maloolin Building by Arash } \\
\text { Mozaffari (Mozafari, 2009) }\end{array}$ \\
\hline
\end{tabular}


other is about iconic buildings with special characteristics which can be reinterpreted. He mentions about his idea of core and crust inspired from traditional Iranian gardens. The opaque main volume of Maloolin building, designed by him is covered with a transparent shell with series of stairs and ramps flowing in between them. The idea of traditional Iranian garden which consists of a central building named koushk which looks towards the whole open space around has been reinterpreted in his projects as the idea of core and crust (Table 6).

\section{Discussion}

Following is a comparative Table 7, which indicates the main ideas of each architect towards the concept of authenticity. Since as was mentioned before, the idea of authenticity consists of two major issues of novelty and relation with past, two main rows of the table show the extracted ideas of each architect about these two indicators. Moreover the main characteristics and implications of the traditional architecture, which have been reinterpreted in their projects, are mentioned.

Reviewing the interviews and analyzing the projects of these selected architects, it can be seen that there exists a common idea in defining the concept of authenticity. According to them, authentic work of architecture is the one, which is based on a new idea that carries the traces of its roots in past experiences. In other words it is not possible to separate novel idea and relation with past because an original idea has to be based on previous experiences. Therefore, concept of authenticity is known as a new interpretation of an older idea. It is not necessary to connect the formal aspects of the project to the past but proposing an idea, which is related to the context, can result in an authentic architectural entity. Also, according to these architects concept of authenticity is related to the authentic "idea".

Although, each of these architects employs different implications of past and tries to reinterpret them, they all mention about the relation with the context as the most dominant issue which can result in authentic architecture. In this way Alireza Taghaboni, and Pouya Khazaeli try to integrate their projects with surrounding environment by reinterpreting the typology of traditional context. Reza Daneshmir represents the idea of traditional central courtyards into vertical open spaces, which connects the building with the city while Rambod Eilkhani tries to create neutral simple facades with flexible characteristics for integrating the heterogeneous urban units. Ramin Mehdizadeh uses the local and natural materials in his projects, which connects the building with surrounding environment and Arash Mozaffari, covers his buildings with a transparent shell and series of stairs and ramps in between which results in visual and physical connection with surroundings as an interpretation of traditional gardens.

\section{Conclusions}

It can be said that the new generation of Iranian architects accept their Iranian background as an important factor in formation of their design ideas and instead of imitating or re-interpretation of the forms of the traditional Iranian architecture, they look for "authentic ideas" in relating their buildings to their contexts. The mentioned architects see authenticity different from the previous generations in that they are not using either traditional forms, patterns

Table 7. Idea of each architect towards novelty and relation with past

\begin{tabular}{|c|c|c|c|c|c|c|}
\hline & R. Daneshmir & A. Taghaboni & R. Eilkhani & P. Khazaeli & R. Mehdizadeh & A. Mozaffari \\
\hline Novelty & $\begin{array}{l}\text { - Play of solid and } \\
\text { void } \\
\text { - Integrating the } \\
\text { building with } \\
\text { the infinite space } \\
\text { of the city and } \\
\text { context }\end{array}$ & $\begin{array}{l}\text { - Based on her- } \\
\text { meneutics (New } \\
\text { interpretation of } \\
\text { an older idea) } \\
\text { - Looking forward } \\
\text { to the future }\end{array}$ & $\begin{array}{l}\text { - Not necessarily } \\
\text { new but being in } \\
\text { continuation of } \\
\text { what exists } \\
\text { - Promoting what } \\
\text { we have today } \\
\text { - New interpreta- } \\
\text { tion of what } \\
\text { exists }\end{array}$ & $\begin{array}{l}\text { - Starting from } \\
\text { somewhere } \\
\text { which exist be- } \\
\text { fore and propos- } \\
\text { ing something } \\
\text { new } \\
\text { - Combination of } \\
\text { modern ideas } \\
\text { and principles } \\
\text { of Iranian archi- } \\
\text { tecture }\end{array}$ & $\begin{array}{l}\text { - Novel idea and } \\
\text { relation with past } \\
\text { - Ideas passed } \\
\text { through the filter } \\
\text { of designer's } \\
\text { mind and car- } \\
\text { rying their own } \\
\text { language }\end{array}$ & $\begin{array}{l}\text { - Evolutionary } \\
\text { process } \\
\text { - Relation with } \\
\text { climatic and } \\
\text { cultural issues of } \\
\text { the context } \\
\text { - Creating the best } \\
\text { solution for a } \\
\text { project } \\
\text { - Simulation but } \\
\text { not imitation }\end{array}$ \\
\hline $\begin{array}{l}\text { Relation } \\
\text { with past }\end{array}$ & $\begin{array}{l}\text { - Not to steal from } \\
\text { the past but to } \\
\text { add to what } \\
\text { exists } \\
\text { - Expanding the } \\
\text { boundaries of } \\
\text { tradition } \\
\text { - Proposing an } \\
\text { exclusive idea } \\
\text { beyond the mere } \\
\text { program of the } \\
\text { project }\end{array}$ & $\begin{array}{l}\text { - Harmony with } \\
\text { typology of tradi- } \\
\text { tional contexts } \\
\text { - Changeable in- } \\
\text { terior spaces by } \\
\text { play of light and } \\
\text { shadow } \\
\text { - Rough texture } \\
\text { - Concept of dual- } \\
\text { ity (solid and } \\
\text { void, open and } \\
\text { close) }\end{array}$ & $\begin{array}{l}\text { - Dynamicity of fa- } \\
\text { çade and interior } \\
\text { spaces } \\
\text { - Flexibility of fa- } \\
\text { çade and interior } \\
\text { spaces } \\
\text { - Relation with } \\
\text { nature } \\
\text { - Integration with } \\
\text { context }\end{array}$ & $\begin{array}{l}\text { - Not to be sepa- } \\
\text { rated from sur- } \\
\text { roundings } \\
\text { - Being independ- } \\
\text { ent } \\
\text { - Being new } \\
\text { - Dealing with } \\
\text { light }\end{array}$ & $\begin{array}{l}\text { - Usage of local } \\
\text { material } \\
\text { - Integration with } \\
\text { context }\end{array}$ & $\begin{array}{l}\text { - Idea of core and } \\
\text { crust inspired by } \\
\text { traditional Ira- } \\
\text { nian gardens }\end{array}$ \\
\hline
\end{tabular}


Table 8. Different approaches in of contemporary Iranian architecture

\begin{tabular}{|l|l|l|l|l|}
\hline \multicolumn{1}{|c|}{ Periods } & \multicolumn{1}{|c|}{$1920-1940$} & \multicolumn{1}{c|}{$1940-1970$} & $1970-2000$ & \multicolumn{1}{c|}{$2000-2020$} \\
\hline $\begin{array}{l}\text { Architectural } \\
\text { idea }\end{array}$ & $\begin{array}{l}\text { Using traditional } \\
\text { forms }\end{array}$ & $\begin{array}{l}\text { Using traditional } \\
\text { patterns and } \\
\text { geometry }\end{array}$ & $\begin{array}{l}\text { Using traditional } \\
\text { implications }\end{array}$ & $\begin{array}{l}\text { Integrating modern technology with traditional } \\
\text { ideas (Making dialogue with world architecture) }\end{array}$ \\
\hline
\end{tabular}

taken from the traditional architecture or implication and reinterpretation of some features of traditional architecture. Rather they see authenticity in bringing new ideas which have a natural root in their culture and traditions using the latest technologies. In their works they search for integrity with the context in a strong way as was the case with traditional architecture. In doing so they use what they have learned from the traditional architecture with a completely new interpretation, in the process of design. This is different than using the features taking from the past's architecture. Their interpretation of what is Iranian is much broader. They respect what can be learned from the past but develop a totally new conceptual interpretation. This allows Iranian architects to apply their ideas in various contexts.

According to Michael Hensel in an article named "Latent Futures of Iranian Architecture" mentioned that in the future, there might be two types of Iranian architecture: one located in the cultural and environmental context of Iran, which originates from past and present local achievements and is re-expressed in an innovative way, and the other to suit different contexts. The first one might be easier to picture, while the second includes how a contextual Iranian sensitivity might differ from other contexts (Hensel, 2012). The table below is a comparative table summarizing the approaches of the all generations of Iranian architects towards authenticity.

This research have tried to demonstrate the ideas of a group of pioneer architects in Iran about authenticity. Yet, there is still a need for further researches to have a more inclusive view of this issue in contemporary Iranian architecture.

\section{References}

aaMag.ir. (2017). Farhad Ahamadi biography. http://memarnet. $\mathrm{com} / \mathrm{fa} /$ node/3189

Ahadi, P. (2011). Influence of traditionalism in tendencies of Iranian contemporary architecture. World Applied Sciences Journal, 12, 496-502.

Asgharzadeh, S., \& Mehrnazar, A. (2009). Scientific Association of Architecture. http://asa.khuisf.ac.ir/

Axworthy, M. A. (2007). Iran: empire of the mind. Penguin Books.

Bahmani, M., \& Karimi, S. (2015). Memarnet. http://memarnet. $\mathrm{com} / \mathrm{fa} /$ node/3189

BaniMasoud, A. (2009). Iranian contemporary architecture. Honar-e-Memari.

Bavar, S. (2008). The advent of new architecture in Iran. Faza Publication.

Curtis, W. J. R. (1983). Authenticity, abstraction and the ancient sense: le Corbusier's and Louis Kahn's ideas of parliment. Perspecta, 20, 181-194. https://doi.org/10.2307/1567073
Daneshmir, R. (2008). About Reza Daneshmir. Sharestan, 4-22.

Diba, D. (2011). A life in contemporary Iranian architecture. Architecture and Urbanism, 27-31.

Diba, D. (2012). Contemporary architecture of Iran. Architectural Design, 82(3), 70-79. https://doi.org/10.1002/ad.1406

Diba, D., \& Dehbashi, M. (2004). Trends in modern Iranian architecture. In Iran: architecture for changing societies. Umberto Allemandi \& C.

Eilkhani, R. (2012). Arsh Design Studio. https://archello.com/ project/dollat-ii

Eilkhani, R. (2009). Shift process practice. https://www.shiftprocesspractice.ir/

Farahi, F. (2012). World of similitude: the metamorphosis of Iranian architecture. Architectural Design, 82(3), 52-61. https://doi.org/10.1002/ad.1404

Frampton, K. (1996). Studies in tectonic culture: the poetics of construction in nineteenth and twentieth century architecture. The MIT Press.

Ghorbani, R. (2019). Resurrecting tradition, rewriting modernity: experiments in contemporary Iranian architecture under economic recession. Journal of Traditional Dwellings and Settlements Review, 61-76.

Habib, F., Etesam, I., \& Mokhtabad, M. (2013). An investigation of global-regional interactional approach at the prominent. International Journal of Architecture and Urban Development, 13-20.

Haj Maleki, M., \& Haghir, S. (2020). Classification of Iranian contemporary architecture, based on trends and challenges. International Journal of Architecture and Urban Development, 10(3), 47-60.

Hasanpour, F., Luwis, M., \& Qinghua, G. (2015). Inconsistent perceptions of early modern Iranian architecture. Paper presented at the 1st International Congress on New Horizons in Architecture and Planning. Tarbiat Modares University.

Hensel, M. (2012). Latent futures of Iranian architecture. Architectural Design, 82(3), 120-127. https://doi.org/10.1002/ad.1410

Iranian Cultural Heritage, Handcrafts and Tourism Organzation. (2014). https://ich.unesco.org/en/10a-urgent-safeguardinglist-00780\&include=slideshow.inc.php\&id $=01111$

Jadidonline. (2005). http://www.jadidonline.com/slideshow/2158/7

Khazaeli, P. (2010). Rai Studio. http://www.raistudio.com/raistudio/External_History/

Kindler, R. A. (1974). Periodical criticism 1815-40: originality in architecture. Architectural History, 17, 22-37. https://doi.org/10.2307/1568343

Mahdavinejad, M., Doroodgar, A., \& Moradchelleh, A. (2012). The impacts of revivalist trends on the contemporary architecture of Iran. Middle-East Journal of Scientific Research, 11(2), 176-183.

Mansour, K. (2003). Flickr. http://www.flickr.com/photos/ mno_k/2780939599/sizes/z/in/photostream/

Mehdizadeh, R. (2007). AbCT. https://abct.kr/

Mirmiran, H. (2004a). Public buildings in Iran: 1920 to the present. https://s3.amazonaws.com/media.archnet.org/system/publications/contents/4749/original/DPC1443.pdf?1384786573 
Mirmiran, H. (2004b). Iran: architecture for changing societies. Aga Khan Award for Architecture.

Mirmiran, H. (2002). Public buildings in Iran: 1920 to the present. In Iran: architecture for changing societies (pp. 39-44). Aga Khan Award for Architecture.

Mirmiran, H. (1999). Journey from material to spirit. Architecture and Urbanism, 42-43.

Mirmiran, H. (2003). Naghsh-e-Jahan Pars Consulting Engineering. http://www.njp-arch.com/default.aspx? cnt=prjd\&pid=58 \&prjgn $=\&$ pin $x=6 \& c=0 \& l=0 \& y=0 \& p=$

Mokhtarshahi Sani, R., \& Mahasti, P. (2013). An inquiry into cultural continuity and change in housing: an Iranian perspective. Sociology Mind, 3(3), 230-237. https://doi.org/10.4236/sm.2013.33031

Mozafari, A. (2009). EBCT. http://www.eba-m.com/
Palmer, C. (2009). Flickr. http://www.flickr.com/photos/41729393@N05/3999250038/sizes/l/in/photostream/

Porphyrios, D. (1998). Classical architecture. Andreas Papadakis Publisher.

Rahimazadeh, R. (2007). Flickr. http://www.flickr.com/photos/8827102@N08/547885504/

Shaygan, D. (2001). Merging of horizons: a letter to the younger generation. Iranian A\&U Magazine, 60-61.

Soheili, J. (2012). Role of social trends in appearance of Iranian national architectural movements. International Journal of Architecture and Urban Development, 2(2), 59-66.

Taghaboni, A. (2010). Next office. http://www.alirezataghaboni.com Veisi, P. (2008). Flickr. http://www.flickr.com/photos/pedramveisi/4025637371/sizes/z/in/photostream/

Warnke, G. (1987). Gadamer: hermeneutics, tradition, and reason. Stanford University Press. 